\title{
Representative Democracy and Social Equality
}

\section{SEAN INGHAM University of California, San Diego, United States}

$W$ hen are inequalities in political power undemocratic, and why? While some writers condemn any inequalities in political power as a deviation from the ideal of democracy, this view is vulnerable to the simple objection that representative democracies concentrate political power in the hands of elected officials rather than distributing it equally among citizens, but they are no less democratic for it. Building on recent literature that interprets democracy as part of a broader vision of social equality, I argue that concentrations of political power are incompatible with democracy, and with a commitment to social equality more generally, when they consist in some having greater arbitrary power to influence decisions according to their idiosyncratic preferences. A novel account of the relationship between power and social status clarifies the role of social equality in the justification of democracy, including a representative democracy in which public officials have more political power than ordinary citizens.

\section{INTRODUCTION}

D emocracy has been justified on the grounds that it is necessary for realizing a broader vision of social equality, of a society whose members relate to each other as equals rather than as occupants of different ranks in a social hierarchy (Anderson 2009; Christiano 2008; González-Ricoy and Queralt 2018; Kolodny 2014; 2019; Viehoff 2014; Wilson 2019). In nondemocratic regimes, privileged elites rule over the masses or privileged social groups rule over the marginalized and excluded-some stand "above" others in a hierarchy. But in a democracy there are not rulers and subjects, but equal citizens, with equal opportunities to influence political decisions. According to some, the equal distribution of political power is thought to be necessary for realizing the ideal of social equality, and it is because democracy is assumed to distribute political power equally-or at least more equally than alternative regimes - that the value of social equality is thought to weigh in its favor.

This justification of democracy is vulnerable to an objection, one with broader implications for how we understand democracy and political equality. Critics point out that representative democracies concentrate decision-making power in the hands of a select few rather than distributing it equally. What are elections if not mechanisms for selecting those citizens who will be given vastly more power to influence political decisions than everyone else? One might describe a certain kind of idealized direct democracy as distributing political power equally, but not a representative democracy. Power cannot be equalized without "destroying representative government altogether" (Dworkin 2002, 191). If the ideal of social equality requires an

Sean Ingham (iD, Associate Professor, Department of Political Science, University of California, San Diego, United States, singham@ucsd. edu.

Received: November 15, 2020; revised: May 14, 2021; accepted: August 23, 2021. First published online: October 5, 2021. equal distribution of political power, then it would seem misguided to justify representative democracy as a means of advancing this ideal.

I present a novel account of the relationship between political power and social status that explains the role that the value of social equality can play in the justification of representative democracy. What social equality requires is an equal distribution, not of power per se but of arbitrary power to influence political decisions according to one's idiosyncratic preferences, and this is what democracy promises, in its electoral form or otherwise. Elected representatives will necessarily have more political power than ordinary citizens, but as representative democracy does not require elected officials to have any more arbitrary power than anyone else, it need not run afoul of the ideal of social equality. Indeed, the value of social equality weighs in its favor when it is compared with nondemocratic regimes in which unaccountable rulers enjoy arbitrary power to decide matters according to their whims. The value of social equality can also play a role in arguments about voting rights and the design of democratic institutions: unequal voting rights, unequal obstacles to exercising those rights, an undue role for money in politics, or anything else that produces inequalities in the distribution of arbitrary, unconstrained power to influence election outcomes marks a departure from the ideal of social equality.

While the primary motivation for the argument is a question about the relationship between social status, power, and the justification of representative democracy, it has broader implications for how scholars conceptualize political equality. Political scientists investigating gaps in participation across racial groups or inequalities in the responsiveness of politicians to rich and poor citizens, for example, frame their research as raising questions about the extent to which existing institutions and policies conform with the values that are allegedly central to democracy, such as citizens' having "equal voice," equal opportunities for influence, or equal political power (Jacobs and Skocpol 2005; Verba, Schlozman, and Brady 1995). A typical 
example, from the preamble to a study of the unequal political influence of rich and poor, is the claim that "the radical idea at the core of democracy" is that "the power to shape public policies should be widely and more or less equally shared among citizens" (Gilens 2012, 12). Such claims must be reconsidered in light of the simple reductio ad absurdum above, however; in a representative democracy, the power to shape public policy is not, and cannot be, equally shared among citizens. Typical claims about equal voice or equal political power fail to explain why the inequalities political scientists investigate - between rich and poor, or between different racial groups-are objectionable on democratic grounds. As they are usually formulated, the claims are crude and overly general, implicating even the inequality between democratic representatives and ordinary citizens. A more nuanced theory of what kind of power ought to be equalized in a democracy, and why, is needed. The argument I make here gives an answer: democratic citizens ought to be equal in the extent of their arbitrary political power rather than power per se because this is what is necessary if they are to become social equals.

\section{THE PROBLEM}

Relational egalitarians argue that part of the justification for democracy is to be found in the value of social equality (Anderson 2009; Christiano 2008; GonzálezRicoy and Queralt 2018; Kolodny 2014; 2019; Viehoff 2014; Wilson 2019). Social equality refers to the ideal of "a society in which people are related to one another as social equals, as opposed to social inferiors or superiors" (Kolodny 2014, 287). When we consider paradigmatic examples of hierarchically organized societies-the American South under Jim Crow, South Africa under apartheid, for example - they are, as a rule, societies in which political power is distributed unequally, with the members of the higher positions in the social hierarchy enjoying greater political power than those below. From this observation one might conclude that inequality in political power contributes to, or perhaps partly constitutes, inequalities of social status. One might then argue along the following lines, as some relational egalitarians have: social equality requires that individuals enjoy equal opportunities to influence political decisions (or equal political power, or equal control over decisions, etc.); democracy provides equal opportunities for influence (or equal political power, etc.), whereas nondemocratic alternatives do not; thus, democracy is necessary for social equality. The problem with this argument, however, is that its second premise does not apply to representative democracies, the core institution of which is a mechanism elections - for selecting those citizens who will be given greater opportunities to influence political decisions than everyone else. ${ }^{1}$

\footnotetext{
${ }^{1}$ Landa and Pevnick (2021b) advance a subtler version of this critique. An earlier version of their paper inspired this article,
}

Kolodny's explanation for why elected officials and ordinary citizens can still relate as social equals is that citizens delegate to the representatives their special power to influence political decisions, and, in general, a principal does not make themselves socially inferior to their agent merely by delegating power (Kolodny 2014, 317). A client does not make herself socially inferior to the attorney she hires to represent her, business owners do not make themselves inferior to the managers to whom they delegate responsibilities, etc.

Describing citizens as delegating power is mainly metaphor, however. An individual voter does not literally delegate power to their elected representative in the way a business owner delegates responsibilities to a manager. If the act of voting for a representative is what is supposed to count as an act of delegation, then citizens who have not voted for their representative have not in this sense delegated any power to them. Even for citizens who have voted for their representative, the metaphor of delegation does not explain why they can relate to each other as social equals. They had no real choice but to "delegate" powers, in this metaphorical sense, either to that candidate or one of the other candidates on the ballot (if there were any). Imagine a slave's owner has died and stipulated in his will that the slave can choose to "delegate" to any of several specified "candidates" the package of rights and powers that constitute ownership of the slave. That the slave has chosen which of the candidates will be his new master, and that he could have chosen someone else to be his master instead, does not change the fact that he and his newly "elected" owner cannot relate to each other as social equals. The democratic representative and ordinary citizen are obviously not in the same kind of relationship, but the explanation for why they are not, and for why they can instead relate to each other as social equals, is not that the citizen has "chosen" the elected representative, from a limited slate of candidates, as the person who will exercise certain powers over her, within an institutional and legal context where there is no escaping the fact that someone will exercise those powers over her. That is also true of the hypothetical slave, and it does not suffice to make inequalities in power compatible with social equality.

Another view might be that inequalities in political power undermine social equality unless they arise under conditions of equal opportunity, the thought being that in a representative democracy, at least under ideal conditions, all citizens have the same opportunities to acquire positions of authority and power. Depending on how it is disambiguated, however, this view renders the requirements for social equality either so permissive that certain nondemocratic regimes satisfy them just as well as representative democracy or so stringent that these regimes fail to satisfy them, but so does representative democracy. If equal opportunity

although I was not able to engage with their most recent version before publication. 
means equal prospects for equally motivated citizens, it is implausible that opportunities for holding elected office could ever be equalized, even under ideal conditions. Not unless "ideal conditions" counterfactualize the distribution of traits like rhetorical ability, charisma, attractiveness, and other personal traits affecting the chances of electoral success. If equal opportunities in this sense were necessary for social equality, then selecting officeholders through random lotteries might be a better means of realizing social equality than elections. ${ }^{2}$ If what social equality requires is instead equal opportunities in the sense that "those similarly endowed and motivated should have roughly the same chance of attaining positions of political authority" (Rawls 1971, 224-5), then representative democracy might satisfy the requirements for social equality (under ideal conditions), but so will certain alternatives to democracy. Consider an idealized political meritocracy, in which high-level public officials with the authority to propose and vote on legislation are selected through a system of exams and promotion (Bell 2015). Assume the exams are designed so that "those similarly endowed and motivated" have "roughly the same chance of attaining positions of political authority." If all social equality requires is equal opportunities in Rawls's sense, then it is not a reason to prefer representative democracy to this kind of political meritocracy (Landa and Pevnick 2021b). ${ }^{3}$

The difficulty with this view illustrates a theme. A justification of representative democracy must identify reasons to consider it better than the relevant alternatives. Besides political meritocracy, a second alternative that is of special interest, because of the attention it has recently received from political theorists, is electoral epistocracy, in which public officials are selected through elections but the right to vote is granted only to those who pass a test of competence (Brennan 2016). Some interpretations of social equality do not identify reasons for considering representative democracy any better than these alternative regimes because they construe the requirements for social equality either too stringently such that both undemocratic regimes and representative democracy fail to meet them or too leniently such that the undemocratic regimes meet the requirements just as well as representative democracy.

Viehoff (2019), for example, argues that "unequal distributions of political power need not amount to objectionable social hierarchy of the sort we associate

\footnotetext{
${ }^{2}$ Of course some relational egalitarians might accept this view and argue, as others have, that lotteries are more democratic than elections (Guerrero 2014; Landemore 2020; Manin 1997; McCormick 2011). For an argument that the connection between lotteries and equal opportunity for influence is not so straightforward, see Landa and Pevnick (2021a).

${ }^{3}$ Apart from the difficulties noted in the main text, it is implausible to suppose that the fairness of the process by which public officials are selected could suffice for concluding that they and ordinary citizens can relate to each other as social equals. Anderson $(2010,105)$ makes a similar point, asking the reader to "imagine a fair lottery, in which everyone had an equal chance to be a plantation overseer, with the losers relegated to gang labor under the overseers' comprehensive and arbitrary rule."
}

with caste or class structures" because hierarchical social status requires not just differential advantages according to different social positions, but also a certain kind of justification. Social hierarchies exist, he argues, only "where those living in a society cannot reasonably see how the unequal distribution of advantages could be given a social justification compatible with everyone's equal fundamental moral significance" (Viehoff 2019, 10-9). If that is right, then representation is compatible with social equality-the inequality between ordinary citizens and elected representatives would not constitute a social hierarchy because people can reasonably see how the inequality in political power can be given a justification compatible with everyone's equal fundamental moral significance. But it is not clear why the value of social equality would be a reason to consider democracy better than epistocracy or political meritocracy. The arguments that Brennan (2016) gives for epistocracy, or that Bell (2015) gives for political meritocracy, for example, are compatible with the assumption that every member of society has equal moral significance.

Wilson (2019) claims social equality requires not equal power but equal sharing of political authority, a condition that is met when everyone's judgments are given adequate consideration and that is compatible with elected officials' wielding more political power than ordinary citizens. This view seems to invite a similar objection, however. With the right cultural education and socialization, the unelected technocrats in Bell's meritocracy, or the "competent" voters in Brennan's epistocracy, might be motivated to give everyone's judgments equal consideration. Yet, intuitively speaking, political meritocracy and epistocracy undermine social equality even if the politically powerful elites in these systems are motivated by an egalitarian, democratic impulse. Of course that supposition may be unrealistic, but the question is whether it would suffice for social equality.

Fourie (2012) argues that "evaluation provides a necessary condition for distinguishing mere differences, on the one hand, and social inequalities, on the other," and claims social inequality arises only when some people are judged superior to others (Fourie 2012, 113). Applying that idea, one might claim that nondemocratic institutions create social inequality because they give public expression to the judgment that some people are superior to others (Christiano 2008), whereas representative democracy merely creates differences in power without comparable value judgments. But that claim is dubious. On one interpretation, the claim might be that inequality in political power conflicts with social equality if it expresses the judgment that some people are superior to others with respect to competence, quality of political judgment, or other traits and abilities that make one fit for wielding political power. So understood, epistocracy and political meritocracy will conflict with social equality, but so will representative democracy. Voters can be expected to make these kinds of evaluative judgments about candidates for office and to vote accordingly-and one should hope so, because, in fact, some people are 
less competent to hold political office. Indeed, central to the thinking of the founders of modern representative democracy was what Manin calls "the principle of distinction," the principle that "power be entrusted to those who possess 'most wisdom' and 'most virtue,' that is, to persons who are superior to, and different from, their fellow citizens" (Manin 1997, 116, emphasis added). This principle might offend egalitarian sensibilities if it is paired with elitist assumptions about the social groups where political virtue is most likely to be found, as it was historically. But once it is unburdened by its historical association with other forms of elitism, it is just a benign statement of a view that any voter implicitly accepts when they vote on the basis of judgments about candidates' competence.

On a less demanding interpretation, the claim might be that judgments of superiority along certain dimensions are compatible with social equality so long as they do not become judgments that one person's interests or claims are more important than another's. ${ }^{4}$ Two people can presumably regard each other as social equals even if one of them is judged to have greater skill in some domain, such as cooking, art, or music. Analogously, one might claim the elected official and ordinary citizen can regard each other as social equals even if the official's superior skill at drafting and evaluating public policy is publicly acknowledged, so long as this judgment of superiority does not become the basis for the judgment that the official's interests deserve greater consideration than anyone else's. However, this less demanding version of the view leaves it unclear why epistocracy or political meritocracy should be incompatible with social equality. Those regimes may give public expression to the judgment that some people have greater skill at evaluating public policies, but that judgment does not imply anyone's interests or claims are more important than anyone else's. Admittedly, in a society with a history of disenfranchising marginalized populations out of indifference to their interests, support for democratic rights might be a way to express egalitarian attitudes; the rights might become a symbol of the value society attributes to each citizen's claims. But, as Brennan argues, appeals to symbolism are a shaky foundation for a justification of democracy: if everyone came to believe that epistocracy produces more equitable results than democracy, then presumably public support for epistocracy could be a way to

\footnotetext{
${ }^{4}$ One might formulate a similar view using Lippert-Rasmussen's (2018, 64-5) distinction between individuals' relating to each other as "moral equals" versus relating to each other as "social equals" and claim that what justifies democracy is the value of the first kind of relational equality, not the second. The problem, parallel to the problem in the main text, is that while the hierarchies in representative democracy are surely compatible with elected officials and ordinary citizens relating to each other as moral equals, so are the hierarchies in nondemocratic versions of political meritocracy or epistocracy. But if the latter hierarchies are incompatible with officials and citizens relating to each other social equals, it remains to be explained why the same cannot be said of the power inequalities in representative democracy.
}

express one's commitment to equality (Brennan 2016, 129)..$^{5}$

The argument I make below differs from previous views in two important respects. First, on the account I propose, inequalities in (arbitrary) power can produce status inequalities independently of how those with greater power choose to exercise their power and independently of the moral beliefs and attitudes they hold. The argument explains why a political meritocracy or epistocracy falls short of the ideal of social equality even if the unelected technocrats or selectively enfranchised voters are motivated by an egalitarian ethos to give adequate consideration to everyone's judgments. Second, the argument does not rest on any claim about what political rights express or symbolize. Like wealth, political rights affect one's social status independently of what they symbolize. Thus Brennan's criticism does not apply. I say more about each point below.

\section{POWER AND SOCIAL STATUS}

I will start by specifying the sense in which elected representatives have more power to influence political decisions than ordinary citizens. After doing so, it will be easier to identify the reasons why equalizing political power-in that sense - is neither necessary nor sufficient for social equality and indeed is not the contribution that democracy might make toward the realization of social equality. These reasons will then point us toward the significance of equalizing citizens' arbitrary power to influence decisions.

Within the large literature on the concept of power, a family of views develops the idea that power is "the ability to effect something" (Morris 2002). In the context of voting, however, it is rare that anyone can deterministically cause one decision rather than another to be taken -in a large election, it almost never happens that anyone's vote is pivotal. To generalize the power-as-ability notion to this context, we can follow an approach from the voting power literature and take an agent's power to be equivalent to their ability to influence the probabilities of outcomes.

To illustrate, take a situation in which a political decision is to be made, such as whether to approve or

\footnotetext{
${ }^{5}$ Gonazález-Ricoy and Queralt (2018, 619-20) respond to Brennan's criticism by claiming that political liberties confer equal status not by virtue of a contingent social convention or cultural symbolism but because they bestow "pervasive, coercive, inescapable, monopolistic, and final" power on their holders. However, they do not explain why these features of political power have implications for social status, or why the same features of elected representatives' power fail to make them the social superiors of ordinary citizens. Note that elected representatives' power is no more "monopolistic" than the bureaucrats' power in political meritocracy; in each case everyone is eligible to compete for it (via elections or exams as the case may be). Christiano (2008) makes the stronger claim that "the disenfranchisement of a group cannot but be seen as a public treatment of that group as inferiors" (92), for reasons that are independent of a society's particular history and inherited political culture; for criticism, see Brennan (2016, 119-21).
} 
reject a piece of proposed legislation or an election between two parties. ${ }^{6}$ Individuals can choose from various plans of action-whether and how to speak with others about the decision, how to vote, and so on - or what in game theory are called strategies. The outcome of the decision-making process depends on individuals' chosen strategies. To assess an agent's power, we adopt the perspective of a hypothetical observer who is uncertain about the strategies other people will choose and represent this uncertainty with a probability distribution over the various possible combinations of other individuals' strategies. ${ }^{7}$ An agent has the power to influence the decision if, by choosing one plan of action rather than another, the agent's choice makes a difference to the probabilities of the outcomes. A reasonable measure of the amount of the agent's power is the maximum difference the agent's choice can make.

Voting. Three individuals, $A, B$, and $C$, are voting by majority rule on whether to approve a proposal. Each person's possible plans of action are to vote to approve or vote to reject the proposal. Taking the perspective of a hypothetical observer who believes $B$ and $C$ each vote with equal probability for either option and each vote independently of the other, the probability that the group votes to approve if $A$ votes for approval is $3 / 4$, whereas the probability that the group votes to approve if she votes to reject the proposal is only $1 / 4$. Thus the amount of $A$ 's power to influence the decision is $1 / 2$.

In this scenario, the amount of an individual's power coincides with the probability the voter's ballot is pivotal, which is the Banzhaf measure of voting power (Banzhaf 1965; 1966; Penrose 1946). The Banzhaf measure is essentially equivalent to Kolodny's characterization of "contributory influence" over decisions:

My view is that by $\mathrm{X}$-ing, I exercise equal contributory influence over a decision just when my X-ing has equal a priori chances of being decisive over the decision, that is, has equal chances of being decisive on the assumption that no pattern of X-ing by others is more likely than any other pattern. (Kolodny 2014, 320-1)

For another illustration, one might suppose the plans of action available to $A$ are not just different voting strategies but more complicated strategies involving communication as well as voting. Her power may

\footnotetext{
${ }^{6}$ I restrict attention to binary decisions in order to bracket complications that are tangential to the argument. See Sher (2020) for a measure of voting power that extends to elections with more than two alternatives.

${ }^{7}$ One approach in the voting power literature is to posit a probability distribution that puts equal weight on all combinations of other individuals' plans of action, but this is not the only approach (Abizadeh 2021; Felsenthal and Machover 1998; Laruelle and Valenciano 2005). The potential disagreements about this issue are orthogonal to the argument I wish to make because on any reasonable resolution of those issues the conclusion must be that elected representatives have greater power to influence political decisions than ordinary citizens do.
}

derive not simply from her voting power but from her ability to persuade $B$ and $C$ to vote one way rather than another, for example.

There are other ways to conceptualize an agent's power to influence a collective decision, but this account suffices for my purposes, as it captures the assumption underlying the objection to relationalegalitarian justifications of representative democracy. By voting for a legislative proposal, instead of against, an elected representative makes an appreciable difference to the probability that the proposal is approved. For a typical ordinary citizen, the citizen's choices make almost zero difference to the probability the proposal is approved. If inequalities in political power were constitutive of social hierarchy, then relational egalitarians would have to object to representative democracy.

Equal power to influence political decisions is neither sufficient nor necessary for social equality, however. To see its insufficiency, consider the following hypothetical scenario:

Voter persecution. A voter has the legal right to cast a ballot in the upcoming election and the ability to exercise his right-no one will interfere with his attempt to go to the polling station and cast a ballot, and his ballot will be counted faithfully, just the same as anyone else's. However, well-armed racist goons wait outside the polling station and announce their intention to beat up the voter if he votes. They have followed through on similar threats in the past. The local officers of the state and courts encourage their terrorism. The voter is, for good reason, certain they will carry out the threat if he votes.

By stipulation, the thugs will not interfere with the voter's attempt to cast a ballot: they intervene only after the voter has voted, and their intervention does not stop the voter's ballot from being recorded and counted faithfully with every other voter's. The voter thus retains the power to influence the election outcome by voting: the probabilities of the possible election outcomes are different depending on whether the voter chooses to stay home or turn out and vote. Moreover, the amount of the persecuted voter's power to influence the election outcome is unaffected by the fact of persecution: the amount of power is just the magnitude of the difference the voter's action makes to the probabilities of the possible election outcomes. The conditions described by Voter persecution are thus compatible with a world in which all citizens have equal power to influence election outcomes.

One might resist this claim, as it would be natural to describe the threats of violence as "disempowering" the voter, but one should not get hung up on the disagreement. However one describes it, the fact is that in the hypothetical scenario, both persecuted and nonpersecuted voters have an ability to make a difference, of the same magnitude, to the probabilities of the possible election outcomes - they have equal Banzhaf power, what Kolodny calls "equal contributory influence," and what by our definition is called equal power to influence the election. Whatever one calls it, the substantive point is that their equality in that respect does not 
suffice for social equality. Not when the ability (power) of some citizens is severely constrained by the fear of retaliatory violence while other citizens can exercise their ability (power) as they please, without fear.

Equal power to influence decisions is not only insufficient but also unnecessary for social equality.

Workers' cooperative. The members of a workers' cooperative appoint one of their own to act as a manager, empowering her to make various decisions about how to assign tasks, fill vacant positions, and coordinate activities among the workers. She alone has the power to make these decisions. At the end of the year her decisionmaking will be reviewed and judged by clearly defined and commonly known criteria, and she will be held accountable: if her decision-making fails to meet the accepted criteria, she will lose not only her managerial position but also her membership in the cooperative. Given the reliability with which this sanction is applied, it is common knowledge among the workers that the manager will make decisions according to the prescribed criteria, even when she might have conflicting goals, such as a desire to allocate coveted positions to her friends over more qualified workers, for example.

In this situation, there is unequal power to influence the decisions delegated to the manager-she makes these decisions unilaterally. Nonetheless, this inequality need not contribute to any social hierarchy within the cooperative. Given the assumptions about how clearly defined the criteria are and the manager's incentives, everyone knows she is merely executing the decision algorithm the workers have prescribed for her rather than acting on her own preferences, such as her preference for a friend to receive a coveted position. If the managerial position does not come with special pay or privileges, there is no reason to think its occupant would acquire a higher social status than anyone else.

The claim that social equality is compatible with the conditions in Workers' cooperative but not Voter persecution, is, I assume, intuitively plausible, and the hypothetical scenarios suggest considerations that might justify it. What seems to matter for social equality is not who has the power to influence decisions per se but rather who has unconstrained power, and whose power is constrained, and how. In Workers' cooperative, the manager's power is constrained; she must exercise her power according to the accepted criteria or lose her source of income. In Voter persecution, the persecuted and nonpersecuted voters alike have power to influence the election outcome, but for the first group their power is severely constrained by the fear of retaliatory violence. Indeed, the constraint facing the persecuted voters is so severe it is "as if" they are powerless; the means by which they could influence the election outcome are so costly that they might as well not have any power, for all practical purposes. (This may be the reason some readers chafe at the claim that the persecuted and nonpersecuted voters have equal amounts of power to influence the election.)

Every actor faces constraints that prevent them from fully realizing their multiple competing goals at the same time. That the manager is prevented from fully realizing two goals at the same time (keeping her job and rewarding her friend) does not distinguish her situation from the generic one. But the constraints on her power are socially significant in a way generic constraints are not. They suffice to create a common expectation among the workers that the manager will not intentionally deviate from the prescribed criteria, whatever her personal sympathies and feelings for other workers or her emotional states more generally; whatever idiosyncratic values, preferences, or tastes she may have; and irrespective of whether she stands to benefit personally from the decisions she makes. Because it will be useful to have a label for strategies in which the agent's exercise of power is independent of these kinds of personal attitudes, values, interests, and preferences, I will refer to them as "impersonal" strategies.

When the constraints on an agent's power suffice to produce a shared expectation that the agent will adopt an impersonal strategy, I will say the agent's power is adequately constrained. If it is not adequately constrained, I will say it is arbitrary. ${ }^{8}$ I should emphasize that these labels are not intended to convey any normative assessment of the agent's power: to describe an agent's power as arbitrary, in this sense, is not necessarily to express criticism or complaint. In some cases an agent's power ought to be arbitrary. The persecuted citizen's power is "adequately constrained," even though the practices producing the constraints are morally objectionable. The constraint on their power creates a common expectation that they will choose to abstain from voting, whatever their preferences over the candidates might be. That they are so constrained reflects not just a violation of principles of justice and morality but also democracy. Democratic voters ought not to suffer this kind of persecution. When they are not persecuted in this way and they can cast a secret ballot and enjoy the normal panoply of rights and protections we associate with democracy, they have arbitrary power to influence election outcomes. They can vote for whichever candidate they like, using any criteria they like, without suffering any consequences; how a voter will exercise her power depends on her preferences, opinions, values, and other idiosyncratic facts about her attitudes. For any given voter, there are no constraints producing a common expectation about whether and how they will choose to vote.

Why should the presence or absence of such constraints matter for social equality? Kolodny suggests social inequality has to do with "some having attributes (for example, race, lineage, wealth, perceived divine favor) that generally attract greater consideration than the corresponding attributes of others" (Kolodny 2014, 295). The term consideration refers in this context to

\footnotetext{
${ }^{8}$ This concept of arbitrary power is similar to concepts traveling under the same name in the literature on republicanism (Ingham and Lovett 2019; Laborde 2008; Lovett 2010; Pettit 1997; 2012; Skinner 1998). My definition is not intended to pick out just the same concept republicans have in mind, although there may be significant overlap in the concepts' extensions.
} 
"those responses that social superiors, as social superiors, characteristically attract," such as "deference, courtesy, a willingness to serve the interests of or to fulfill the claims or commands of, efforts to ingratiate or curry favor with, and so on." Amending slightly Kolodny's claim, I will assume differences in social status are constituted, partly, by some but not all people having attributes that, as a matter of common awareness, incentivize others to give them special consideration, such as to ingratiate themselves with them and to be especially solicitous of their wishes, or by some but not all people lacking attributes that, as a matter of common awareness, incentivize courtesy and respect. As shorthand, I will refer to the attributes that satisfy this condition as the bases for unequal status. The claim is that differences in such attributes imply, all else being equal, differences in social status. (We have to add a ceteris paribus clause because one person could be, say, wealthier than a second, yet still of lower status because of differences in bases for unequal status other than wealth.) Let me clarify the two amendments I am making to Kolodny's claim before returning to the question about constrained versus arbitrary power.

First, for high status it is not enough that a person's attributes attract special consideration; there must also be a shared awareness of this dynamic among those for whom the person has high status. A person's status is a public fact about them: one cannot coherently imagine someone secretly having a high status within a group unbeknownst to the rest of the group. Lucky Luke's status at school does not increase simply because, unbeknownst to anyone, he has won the lottery and is prepared to shower riches on his friends. People must know this fact in order for his wealth to attract special consideration. Moreover, this fact must be not just known by all but (approximately) common knowledge (people know that everyone knows it, know that everyone knows everyone knows it, and so on). If he privately tells each person at school about his winnings but swears everyone to secrecy, then his wealth will attract special consideration, but everyone will falsely believe everyone else regards him in the same light they did before his turn of good luck. His social status within the group will remain the same.

Second, what seems to matter for one's status is not just how attributes like wealth, race, lineage, and so on can attract differential consideration, but how they can create incentives for differential consideration. Small children have attributes that "attract" special solicitude from adults, such as when adults indulge the whims of a small child because they find him charming and amusing. In this case the child's special treatment indicates nothing about his social status. But suppose the same behavior in adults springs from a different motive: if the child is the heir to the throne, then adults might try to curry favor not because of the child's charms but rather because of the material benefits he can bestow upon them when he becomes king. Apart from these material benefits, people will also be incentivized to give the heir special consideration because of the costs of violating the social norms and expectations that define the institution of the monarchy. More generally, the status that attaches to occupancy of certain social positions or membership in privileged social groups (e.g., those defined by gender, race, etc.) is constituted, in part, by the fact that people have incentives to adhere to the social norms prescribing preferential treatment for the members of these groups. The costs of violating social norms are not always the relevant incentive, however. Some attributes like wealth and (as I will argue) arbitrary power can be distinct bases for unequal status independently of the mechanism involving social norms (although their incentivizing effects will of course still be contingent on background social structures-for example, markets or structures of trade in the case of wealth).

It is worth emphasizing that on this account, differences in status do not disappear just by people deciding to treat each other differently, such as treating each other in the manner one would expect social equals to treat each other. If the social structures in light of which an attribute produces incentives for special consideration remain in place, differences in that attribute still imply, all else being equal, differences in status. In a feudal society, the lord and his servant might be friends, and they might be committed to treating each other as if they were social equals, for they might (correctly) regard each other as moral equals - that is, as persons whose fundamental interests and rights have the same moral importance. But so long as membership in the feudal categories creates, for them and for others, commonly recognized incentives for differential treatment, the social hierarchy remains. ${ }^{9}$

Consider now the significance of arbitrary versus constrained power in light of this account. My claim is that unequal arbitrary power, but not unequal power per se, is a basis for unequal status. I add caveats and clarifications below, but consider, first, how the given examples support the claim. When the manager in Workers' cooperative is choosing which of two coworkers to promote to a coveted position, her incentives are powerful enough to create a common expectation that she will decide according to the prescribed criteria, giving the position to whichever of the two candidates is most qualified, independently of her personal feelings toward them, her own values and preferences, and any personal benefits she might derive from one or the other decision. Thus the candidates have no incentives to ingratiate themselves with her or to flatter her out of a worry that her feelings toward them will affect her decision. ${ }^{10}$ She might prefer for positions to be awarded on the basis of experiences or skills distinct from those that the prescribed criteria designate as qualifications,

\footnotetext{
${ }^{9}$ This is not to deny that if enough people consistently treat each other as if they were social equals, then a possible effect might eventually be the elimination of the social hierarchy. This could happen if the incentives for differential treatment arise from social norms and expectations for how one ought to behave and if the norms erode as deviations from them accumulate.

${ }^{10}$ That is, they do not have any such incentives just in virtue of the manager's special power to influence these decisions; she could have other attributes that incentivize this kind of special consideration of course.
} 
but the candidates have no incentives to learn about her preferences or to adjust their behavior in light of them. Because her special power to influence decisions, being adequately constrained, does not create commonly recognized incentives for other people to give her special consideration, it is not a basis for unequal social status.

The conclusion would be different if her power were not constrained in the same way, however. Suppose the accountability mechanism is imperfect in that the penalty for deviating from the criteria is less severe than the loss of her job and the probability her reviewers would spot deviations is low. Because the constraint on her power is now trivial, other workers may reasonably wonder whether her decisions will be based on the prescribed criteria or instead her personal feelings toward her colleagues, her moral values, or her idiosyncratic opinions and preferences. Now it pays to learn which skills and traits she thinks are important for whoever occupies the coveted role; interested candidates have incentives to take note of her preferences and acquire those skills. Now her coworkers have incentives to flatter her, to present themselves in a positive light, to avoid giving offense. The trivial constraints on her power fail to create a common expectation that she will follow an impersonal strategy. Her power is arbitrary. It creates incentives for the other workers to give her feelings and wishes special consideration, and the shared awareness of this dynamic is what constitutes her elevated status.

Such incentives arise when some have greater arbitrary power than others even if everyone has, strictly speaking, the same amount of power simpliciter. In Voter persecution, all voters may have the same amount of power to influence election outcomes, but political parties will have stronger incentives to consider the opinions and preferences of those voters whose power to influence the election outcome is arbitrary, being unconstrained by fear of retribution. Political parties will have incentives to flatter these voters, to affirm the importance of their interests and concerns and the legitimacy of their claims on society, because these are the voters who can be expected to turn out to vote if they prefer one party to the other and whose preferences over the outcome will matter. Political parties will have little or no incentive to consider the opinions and preferences of persecuted voters, for there is a common expectation that they will choose to stay home whatever their political opinions and preferences happen to be, given that they are constrained to choose between exercising their right to vote and keeping themselves safe. The parties and anyone else with a stake in the election can afford to ignore them. Moreover, the fact that political parties can afford to ignore the persecuted voters but have incentives to flatter and give special consideration to the voters whose power to influence elections is unconstrained will not be a secret. It will be plain to all, indeed as good as common knowledge, which is why the unequal distribution of unconstrained political power among the voters is the basis for a difference in status.
This account of social inequality and arbitrary power generates a simple rebuttal to Brennan's (2016) argument that if democratic rights have implications for a person's social status, it is only in certain times and places where a history imbues these rights with cultural significance, much as the action of raising the middle finger is insulting only in the right cultural context. The preceding explanation for why inequalities in arbitrary power have implications for status does not rest on any claim about what political rights express or symbolize. It is the incentives that a system of democratic rights creates, not the egalitarian values that society's support for such rights expresses, that explains their connection with equal status.

The account also explains why a regime like electoral epistocracy would violate the requirements for social equality even if the enfranchised voters were motivated to treat their disenfranchised counterparts as moral equals, giving careful consideration to their interests and judgments (elicited through opinion surveys, say). As noted above, the lord and his servant do not become social equals just because the lord, motivated by an egalitarian ethos, gives careful consideration to the interests and judgments of the servant. Inequalities in arbitrary power to influence political decisions create commonly recognized incentives for differential treatment. If those incentive structures remain intact, then so do differences in social status, however considerate the powerful might be of their social inferiors.

Let me add some qualifications to the claim about arbitrary power and status. I assume we are dealing with arbitrary power to influence decisions in which each member of a reference group potentially has something at stake. That I have arbitrary power to influence a decision about the color that my bedroom walls are painted, but you do not, is not a basis for an inequality in status between us: the decision does not concern you, so my power does not create incentives for you to give me special consideration. There is more to say about the relevant condition, but however we flesh it out, by their nature political decisions are sure to satisfy it.

For a person's arbitrary power to be a basis for status, the members of the reference group must be aware of it, and this situation must persist long enough for them to be able to engage in the kinds of behaviors that amount to giving this person special consideration. Viehoff gives an example in which a member of an egalitarian nomadic tribe stumbles into a position where he alone can negotiate an agreement with another tribe (Viehoff 2019, 20). That he has more arbitrary power to influence this agreement than the other tribe members will not create incentives for anyone to give him special consideration, and thus it need not have any implications for his status, because no one is even aware he will acquire this power prior to the time when he exercises it. Like the previous qualification, this one does not significantly limit the argument's applicability to politics, where the structures affecting the distribution of arbitrary power are generally public and enduring. 
Finally, a point to bear in mind when assessing the claim against putative counterexamples is that there is more than one basis for unequal status - not just arbitrary power to influence collective decisions but other attributes like wealth, beauty, etc. That one person can have more arbitrary power to influence a collective decision than a second yet nonetheless be of lower status, does not discredit the claim because the two may differ with respect to the other bases for status. For the same reason, equality of arbitrary power is insufficient for social equality. ${ }^{11}$

Having seen the importance of distinguishing between constrained and unconstrained power, we are now in a better position to see how the value of social equality might figure in the justification of representative democracy.

\section{CONSTRAINING POLITICAL REPRESENTATIVES}

Recall now the structure of the dialectic prompting the inquiry into the relationship between political power and social equality. Some relational-egalitarian justifications of democracy appeal to the value of egalitarian power relations and claim democracy, and only democracy, distributes political power equally, at least under ideal conditions. This equality is held to be necessary for the achievement of social equality, which is therefore taken to be a reason to value democracy. The skeptic objects that representative democracy does not distribute political power equally; in fact, equalizing political power would destroy representative government (Dworkin 2002, 191). Not only is inequality of political power inherent in the concept of representative democracy, but, the skeptic continues, representative democracy also fares no better than certain nondemocratic alternatives, such as political meritocracy, when evaluated against the putative ideal of equal political power because in both regimes a select few exercise power over everyone else. The perspective of our imagined interlocutor is familiar from a strain of democratic theory that describes electoral democracy not as a political system without rulers and subjects but as just a particular way of selecting who will rule over everyone else (Dunn 1999; Landa and Pevnick 2020; Riker 1982; Schumpeter 1942).

I argued that what is necessary for social equality is not equal political power per se but rather equality in the distribution of arbitrary power to influence political decisions. Reconstructing the relational-egalitarian justification of democracy along these lines, the claim would be that democracy comes closer to equalizing the distribution of arbitrary power to influence political decisions than nondemocratic alternatives, under realistic, nonideal conditions. Ideally, democratic officials would have no arbitrary power and all citizens would

\footnotetext{
${ }^{11}$ Garrau and Laborde (2015) and Schuppert (2015), arguing that nondomination is insufficient for social equality, make points that are relevant here.
}

have the same arbitrary power to influence elections, fulfilling the requirements that the ideal of social equality imposes on the distribution of arbitrary power. In this ideal world, elected officials would not properly be described as "rulers" at all-rulers can exercise power according to their arbitrary whims. If elected officials were not just adequately constrained but, moreover, constrained to use their power for publicly defensible ends, they could accurately be described as public servants rather than rulers; those subject to the laws they enact would have "the status of citizens, not subjects" (cf. Anderson 2009, 215; Kolodny 2014, 318).

This justification does not invite the same skeptical objection as the original. The first point to make is that an unequal distribution of arbitrary power is not a consequence of constitutive features of representative democracy-equalizing arbitrary power would not "destroy" representative government. The explanation was already foreshadowed in the discussion of Workers' cooperative, where the manager acts as a kind of representative, but with adequately constrained power to influence collective decisions at the firm. In principle, it is possible that democratic representatives face similar constraints on their exercise of power, such that there is a common expectation that they will adopt impersonal strategies in which their actions are independent of their own preferences, feelings, and whims.

One possibility is that an elected official is constrained to do what his constituents want him to do. If winning reelection is valuable enough and deviating from what his constituents want is a sufficiently reliable means of losing the next election, then there may be a common expectation that the elected official will follow a strategy of doing whatever the constituents want. ${ }^{12}$ Voters' policy preferences are not the only potential source of constraint, however. Suppose voters engage in retrospective voting, ignoring the specific actions an elected official has taken but holding the official accountable for outcomes associated with good governance such as material prosperity, domestic stability, etc. (Fiorina 1981; for a review of related literature, see Ashworth 2012). The representative may therefore ignore constituent opinion about specific policy decisions, choosing whichever actions he believes will lead to the outcomes associated with good governance. If the electoral incentives are strong enough, there may be a common expectation he will follow an impersonal strategy of this kind, in which his own policy preferences and political values play no role in his decision making. In either of these hypothetical scenarios, the elected official's power would be adequately constrained. While these are stylized models of electoral democracy, and in some respects quite unrealistic, they

\footnotetext{
12 As this example illustrates, the constraints on an elected representative's power might suffice for the purpose of social equality, even if they are undesirable from other points of view. Indeed, all kinds of constraints could suffice for the purpose of social equality, on my account, even constraints that are morally objectionable or conflict with other democratic values, apart from social equality. Social equality is not the only value that should inform the design of democratic institutions.
} 
nonetheless show that inequalities in arbitrary power are not necessary consequences of the constitutive features of representative democracy.

That claim is compatible with other models of representation, including the view that representatives ought to act as a kind of "trustee," making decisions based on their own judgments about what promotes the public interest. ${ }^{13}$ Indeed, anyone who holds the trustee view should also favor institutions and norms that create strong incentives for elected officials to act as trustees rather than choosing plans of action that advance their own personal agendas. If the incentives are strong enough to create a common expectation that the elected official will act as a trustee-supporting decisions if and only if, in their sincere judgment, the decision advances the common interest-then all the better, and in that case the representative's power is adequately constrained. Like the manager in Workers' cooperative, the trustee follows an impersonal strategy of making whatever decisions are best according to certain criteria - in this case, the public good-independently of their personal feelings, preferences, and interests. As Pitkin points out, to call a representative a "trustee" is to emphasize that he "is not just a person doing whatever he pleases or acting just for himself," but rather has an "obligation to others" (Pitkin 1967, 128). Just as we try to design laws that compel financial fiduciaries to honor their obligations to clients, so we may also hope to design democratic institutions and foster norms that, as far as possible, compel elected representatives to carry out their obligations as constituents' trustees.

Even if inequalities in arbitrary power are not inherent in the concept of representative democracy, they may still be inevitable under realistic conditions. Elections are an imperfect mechanism of accountability. The link between the elected official's actions and the threatened sanction of removal from office is not so reliable as what was stipulated, for the purposes of clarifying concepts, in Workers' cooperative. The representative may reasonably believe that acting as a good custodian of his constituents' interests is likely to leave him, at reelection time, with nearly the same observable record as acting according to his personal whims and idiosyncratic policy preferences. Voters' threat of retrospectively conditioning their votes on observed past performance would then fail to constrain the representative. There is arguably room for improving existing forms of representative democracy, and strengthening accountability in particular, but there

\footnotetext{
${ }^{13}$ The claim is also compatible with Beerbohm's (2012, chap. 8) model of "principled representation," provided it is possible to create incentives for representatives to treat their constituents' judgments about principles of justice as exclusionary reasons in their deliberations, as he argues they ought. What I say here does not apply to all theories of representation, however. In what Mansbridge (2003) calls "gyroscopic" representation, the elected representative is not supposed to be responsive to external incentives and is not supposed to be accountable to voters in any traditional sense. It may be that socalled gyroscopic representation implies what I refer to as arbitrary power.
}

are limits. A skeptic may therefore question whether the value of equalizing arbitrary power gives us any reason to prefer representative democracy to nondemocratic alternatives, like political meritocracy, under realistic conditions.

To strengthen the objection, the skeptic might also note that a political meritocracy could avail itself of nonelectoral mechanisms for constraining the power of public officials, however imperfectly. These might include nonelectoral mechanisms, like the norms and incentives sustaining the rule of law, that would also have to be part of the explanation for how representative democracies flatten the distribution of arbitrary political power under realistic conditions to the extent they do. Think of a judge who, appointed for life, is not formally accountable to anyone for her rulings but who (let us suppose for the sake of argument) nonetheless has incentives to decide cases according to her sincere judgments about what the law requires. These incentives may derive from a concern with her reputation and from the knowledge that deviating from the plan of deciding according to her sincere judgment will produce poorly justified decisions and harm her reputation. If she has no conflicts of interest, then the incentives could be strong enough to produce a common expectation that she will follow that impersonal strategy. She would have no more arbitrary power to influence the outcome of the case than anyone else. If one accepts the arguments in the previous section, then her holding the role of judge need not prevent her and other citizenssay the plaintiff in the case-from relating to each other as social equals. Of course in practice this may rarely be true; I am not offering this as a realistic description of the position of judges in actual regimes, democratic or otherwise. The point is only to highlight a conceptual possibility to which the reconstructed version of the relational-egalitarian argument would have to attend: an actor's power can be constrained even if they are not, strictly speaking, accountable to any particular person for its exercise. ${ }^{14} \mathrm{~A}$ comparative justification of representative democracy would thus have to consider whether this and other nonelectoral mechanisms might work to constrain power in a political meritocracy.

It would also require a more nuanced measure of arbitrary power than what I have given, one that allows meaningful comparisons between the amounts of arbitrary power public officials have in different types of regime. The analysis I have given supports binary judgments: power is either adequately constrained, if the constraint produces a common expectation that power will be exercised according to an impersonal strategy, or it is arbitrary. A more nuanced view is suggested by a more realistic variation on Workers' cooperative, where the manager's incentives to exercise power only according to the prescribed criteria are

\footnotetext{
${ }^{14}$ This example also illustrates how an actor's power can be constrained even if the actor is not under any person's or group's control. This is one reason I prefer the explanation given here to Lovett's (2021) explanation of why representative democracy is compatible with social equality, which emphasizes popular control. See also Viehoff $(2019,23)$.
} 
weaker but still significant. In more realistic versions of the story, the manager's incentives might create a common expectation that she will exercise power according to a strategy that is not "impersonal," as defined above, but partially depersonalized, as it were: one in which her personal feelings, preferences, and values exert some influence on her decision making, yet less influence than they might in the absence of the imperfect accountability mechanism. We might then say that she has more or less arbitrary power, or is constrained to a more or less significant extent, depending on how closely her situation approximates the ideal type of the adequately constrained agent. This imperfectly constrained power would still create incentives for other people to give the agent's feelings, preferences, and interests special consideration. But the incentives would be weaker or stronger depending on the significance of the constraints and how much influence these attitudes and motivations are expected to have on the agent's exercise of power. Plausibly, the influence on inequalities in social status would be more or less depending on the strength of these incentives.

Amending the account of arbitrary power in the manner suggested, we might then compare representative democracy with an alternative regime like political meritocracy by comparing the extent to which the personal feelings, preferences, and interests of imperfectly constrained public officials can be expected to influence collective decisions in the two kinds of regime. Under realistic conditions, the constraints on democratic officials may be weak enough that they would be expected to exercise power according to strategies that are only partially "depersonalized." The same will no doubt be true of public officials in any regime. However, one might conjecture that the typical institutions and political cultures of representative democracies still work more effectively to constrain the power of high-level public officials than nondemocratic alternatives, rendering the personal whims, preferences, and interests of the first set of actors less consequential for political decisions. For example, in a political meritocracy, low-level officials can be held accountable to officials higher up in the hierarchy, but at the top there are actors who are accountable to no one and who will be only imperfectly constrained by political norms. Compared with their counterparts in democracies, who are constrained by norms as well as electoral accountability mechanisms, one might conjecture that the preferences and interests of high-ranking officials in a political meritocracy could be expected to play a more consequential role in their exercise of power. Compared with democracy's elected officials, they are, one might argue, more aptly described as a "ruling elite." If this conjecture were born out, then the value of social equality would be a consideration favoring representative democracy over political meritocracy.

\section{CONCLUSION}

I conclude by drawing out the implications of the argument for questions about voting rights. On the account I have proposed, social equality requires an equal distribution of arbitrary power to influence political decisions. Logically speaking, that requirement could be met if no one had any arbitrary power. That is not how representative democracy would meet it, however. Even under ideal conditions, democratic voters would have arbitrary power to influence elections; there would be no constraints on their power producing a common expectation that they will exercise it according to impersonal strategies, strategies in which their preferences, values, and interests play no role. Indeed, to apply such constraints, even impartially and equally, would undermine the point of democratic elections as many people understand them. What representative democracy requires is not the absence of arbitrary power but the absence of inequalities in arbitrary power. Public officials who have more power to influence political decisions than ordinary citizens ought to be adequately constrained through norms, laws, electoral accountability, and other mechanisms. Ideally, all adult citizens ought to have the same amount of arbitrary power to influence elections. ${ }^{15}$

Some modes of compromising democracy unambiguously violate that principle, such as when marginalized social groups are excluded from the electorate or when the wealthy are effectively able to purchase extra political influence on top of the power everyone enjoys in virtue of basic democratic rights. But even if all citizens have the same amount of power to influence elections, the principle can still be violated if laws, institutions, or social practices make the exercise of that power especially burdensome for some citizens. The hypothetical example of voter persecution was a stylized and extreme illustration of the point. Another example might be certain voter identification laws. In the U.S., a concern with such laws is that the requirement might disproportionately burden racial minorities and therefore depress their turnout in elections - which is, plausibly, the purpose of the state legislatures that enact these requirements: for example, in Texas, "hunting and gun permits, which Whites are statistically more likely to possess, are legitimate forms of ID but social service cards, more often held by Blacks and Latinos, are not" (Barreto et al. 2019). These laws are often described as "disempowering" minority voters, but a more precise description is that they make it more costly for minority voters to exercise their power. They impose extra constraints on the power of citizens who do not already have the required identification: these

\footnotetext{
15 This view of democracy is similar to the account Landauer (2019) finds in classical Greek discussions of democracy, according to which ordinary citizens, in their capacity as jurors and voters, were not to be held accountable for their actions even as great importance was placed on mechanisms for holding political elites accountable, especially orators advising the people in the assembly. One difference between the two conceptions of democracy is that while the distinction between unaccountable and accountable political actors may correlate in practice with the distinction between unconstrained and constrained power, the two distinctions are not equivalent. See the example, above, of the judge who is not accountable to any agent or group of agents but whose power is nevertheless constrained.
} 
citizens are forced to choose between exercising their right to vote and whatever they must forego, in terms of time and money, to acquire the needed identification. The additional constraint threatens to create an expectation, shared by political parties, that they will follow "impersonal" or partially depersonalized strategies in which they abstain from participating in the election independently of their preferences over the candidates. They would then have less arbitrary power to influence election outcomes than voters who do not face the same constraint and whose attitudes toward the candidates are more likely to influence whether and how they vote. This difference in arbitrary power would be expected to shape political parties' incentives to give consideration to the preferences of minority voters, as compared with white voters, exacerbating the differences in social status that already exist on account of differences in wealth, education, racial stigmatization, etc.

The argument of the paper thus shows not only how one can reconcile the value of social equality with the inequality in political power between elected representatives and ordinary citizens and how it can play a role in the justification of representative democracy over alternatives like political meritocracy. It also shows how this value can inform normative debates about the design of democratic institutions. Laws and policies that impose targeted burdens on select groups of citizens, increasing their costs of exercising political power, frustrate progress toward the ideal of social equality.

\section{ACKNOWLEDGMENTS}

For comments on previous versions of the paper, the author thanks workshop participants at the University of California, Irvine, the University of California, San Diego, and Stanford University; panelists and audience members at the 2019 meeting of the Philosophy, Politics, and Economics Society; Matthew Landauer, Frank Lovett, Agustina Paglayan, Zeynep Pamuk, Emma Saunders-Hastings, and David Wiens; and this journal's anonymous referees and editors.

\section{CONFLICT OF INTEREST}

The author declares no ethical issues or conflicts of interest in this research.

\section{ETHICAL STANDARDS}

The author affirms this research did not involve human subjects.

\section{REFERENCES}

Abizadeh, Arash. 2021. "Counter-Majoritarian Democracy: Persistent Minorities, Federalism, and the Power of Numbers." American Political Science Review 115 (3): 742-56.
Anderson, Elizabeth. 2009. "Democracy: Instrumental vs. NonInstrumental Value." In Contemporary Debates in Political Philosophy, eds. Thomas Christiano and John Christman, 213-27. Oxford: Wiley-Blackwell.

Anderson, Elizabeth. 2010. The Imperative of Integration. Princeton, NJ: Princeton University Press.

Ashworth, Scott. 2012. "Electoral Accountability: Recent Theoretical and Empirical Work." Annual Review of Political Science 15: 183-201.

Banzhaf, John F. 1965. "Weighted Voting Doesn't Work: A Mathematical Analysis." Rutgers Law Review 19: 317-43.

Banzhaf, John F. 1966. "Multi-Member Electoral Districts. Do They Violate the 'One Man, One Vote' Principle." The Yale Law Journal 75 (8): 1309-38.

Barreto, Matt A., Stephen Nuño, Gabriel R. Sanchez, and Hannah L. Walker. 2019. "The Racial Implications of Voter Identification Laws in America." American Politics Research 47 (2): 238-49.

Beerbohm, Eric. 2012. In Our Name: The Ethics of Democracy. Princeton, NJ: Princeton University Press.

Bell, Daniel A. 2015. The China Model: Political Meritocracy and the Limits of Democracy. Princeton, NJ: Princeton University Press.

Brennan, Jason. 2016. Against Democracy. Princeton, NJ: Princeton University Press.

Christiano, Thomas. 2008. The Constitution of Equality: Democratic Authority and Its Limits. Oxford: Oxford University Press.

Dunn, John. 1999. "Situating Political Accountability." In Democracy, Accountability, and Representation, eds. Adam Przeworski, Bernard Manin and Susan Stokes, 329-44. Cambridge: Cambridge University Press.

Dworkin, Ronald. 2002. Sovereign Virtue: The Theory and Practice of Equality. Cambridge, MA: Harvard University Press.

Felsenthal, Dan S., and Moshé Machover. 1998. The Measurement of Voting Power: Theory and Practice, Problems and Paradoxes. Cheltenham: Edward Elgar.

Fiorina, Morris P. 1981. Retrospective Voting in American National Elections. New Haven, CT: Yale University Press.

Fourie, Carina. 2012. "What Is Social Equality? An Analysis of Status Equality as a Strongly Egalitarian Ideal." Res Publica 18: $107-26$.

Garrau, Marie, and Cécile Laborde. 2015. "Relational Equality, Non-Domination, and Vulnerability." In Social Equality: On What It Means to be Equals, eds. Carina Fourie, Fabian Schuppert, and Ivo Wallimann-Helmer, 45-64. Oxford: Oxford University Press.

Gilens, Martin. 2012. Affluence and Influence: Economic Inequality and Political Power in America. Princeton, NJ: Princeton University Press.

González-Ricoy, Inigo, and Jahel Queralt. 2018. "Political Liberties and Social Equality." Law and Philosophy 37 (6): 613-38.

Guerrero, Alexander A. 2014. "Against Elections: The Lottocratic Alternative." Philosophy \& Public Affairs 42 (2): 135-78.

Ingham, Sean, and Frank Lovett. 2019. "Republican Freedom, Popular Control, and Collective Action." American Journal of Political Science 63 (4): 774-87.

Jacobs, Lawrence R., and Theda Skocpol. 2005. Inequality and American Democracy: What We Know and What We Need to Learn. New York: Russel Sage Foundation.

Kolodny, Niko. 2014. "Rule over None II: Social Equality and the Justification of Democracy." Philosophy \& Public Affairs 42 (4): 287-336.

Kolodny, Niko. 2019. "Being under the Power of Others." In Republicanism and the Future of Democracy, eds. Yiftah Elizar and Geneviève Rousselière, 94-114. Cambridge: Cambridge University Press.

Laborde, Cécile. 2008. Critical Republicanism: The Hijab Controversy and Political Philosophy. Oxford: Oxford University Press.

Landa, Dimitri, and Ryan Pevnick. 2020. "Representative Democracy as Defensible Epistocracy." American Political Science Review 114 (1): 1-13.

Landa, Dimitri, and Ryan Pevnick. 2021a. "Is Random Selection a Cure for the Ills of Electoral Representation?" Journal of Political Philosophy 29 (1): 46-72.

Landa, Dimitri, and Ryan Pevnick. 2021b. "Can Egalitarian Considerations Justify Representative Democracy?" Unpublished Manuscript. 
Landauer, Matthew. 2019. Dangerous Counsel: Accountability and Advice in Ancient Greece. Chicago: University of Chicago Press.

Landemore, Hélène. 2020. Open Democracy: Reinventing Popular Rule for the Twenty-First Century. Princeton, NJ: Princeton University Press.

Laruelle, Annick, and Federico Valenciano. 2005. "Assessing Success and Decisiveness in Voting Situations." Social Choice and Welfare 24 (1): 171-97.

Lippert-Rasmussen, Kasper. 2018. Relational Egalitarianism: Living as Equals. Cambridge: Cambridge University Press.

Lovett, Frank. 2010. A General Theory of Domination and Justice. Oxford: Oxford University Press.

Lovett, Adam. 2021. "Must Egalitarians Condemn Representative Democracy?" Social Theory and Practice 47 (1): 171-98.

Manin, Bernard. 1997. Principles of Representative Government. Cambridge: Cambridge University Press.

Mansbridge, Jane. 2003. "Rethinking Representation." American Political Science Review 97 (4): 515-28.

McCormick, John P. 2011. Machiavellian Democracy. Cambridge: Cambridge University Press.

Morris, Peter. 2002. Power: A Philosophical Analysis. Manchester: Manchester University Press.

Penrose, L. S. 1946. "The Elementary Statistics of Majority Voting." Journal of the Royal Statistical Society 109 (1): 53-7.

Pettit, Philip. 1997. Republicanism: A Theory of Freedom and Government. Oxford: Oxford University Press.

Pettit, Philip. 2012. On the People's Terms: A Republican Theory and Model of Democracy. Cambridge: Cambridge University Press.
Pitkin, Hanna F. 1967. The Concept of Representation. Oakland: University of California Press.

Rawls, John. 1971. A Theory of Justice. Cambridge, MA: Harvard University Press.

Riker, William. 1982. Liberalism against Populism: A Confrontation between the Theory of Democracy and the Theory of Social Choice. Prospect Heights, IL: Waveland Press.

Schumpeter, Joseph. 1942. Capitalism, Socialism, and Democracy. New York: Harper \& Brothers.

Schuppert, Fabian. 2015. "Non-Domination, Non-Alienation, and Social Equality: Towards a Republican Understanding of Equality." Critical Review of International Social and Political Philosophy 18 (4): 440-55.

Sher, Itai. 2020. "Freedom and Voting Power." Working Paper. https://sites.google.com/site/itaisher/research?authuser $=0$.

Skinner, Quentin. 1998. Liberty before Liberalism. Cambridge: Cambridge University Press.

Verba, Sidney, Kay Lehman Schlozman, and Henry E. Brady. 1995. Voice and Equality: Civic Voluntarism in American Politics. Cambridge, MA: Harvard University Press.

Viehoff, Daniel. 2014. "Democratic Equality and Political Authority." Philosophy \& Public Affairs 42 (4): 337-75.

Viehoff, Daniel. 2019. "Power and Equality." Chap. 1 in Oxford Studies in Political Philosophy, vol. 5, eds. David Sobel, Peter Vallentyne, and Steven Wall. Oxford: Oxford University Press.

Wilson, James. 2019. Democratic Equality. Princeton, NJ: Princeton University Press. 